\title{
Ultrasonographic Grey Scale Analysis (GSA) of the equine uterus - practical relevance for fertility prognosis
}

\author{
K.J. Lorber', C.P. Bartmann', E. Klug', Uta Blaich'1, Svenja Petzold', H. A. Schoon² and R. Hermes ${ }^{3}$ \\ 1 Klinik für Pferde, Tierärztliche Hochschule Hannover, Germany \\ 2 Institut für Veterinär - Pathologie, Universität Leipzig, Germany \\ 3 Institut für Zoo- und Wildtierforschung (IWZ) Berlin, Germany
}

\begin{abstract}
Summary
In human medicine computer assisted GSA is part of specific examinations like heart transplantation Lieback et al. (1991), hepatic cirrhosis Raeth et al. (1984), evaluation of changes of the thyroid gland Mueller et al. (1989). Hermes et al. $(1997,1998)$ applied this method in zooand wildlife medicine.

With computer assisted GSA from ultrasonographic images of the equine endometrium it was possible to distinguish between physiological and inflammatory changed endometrium. The advantages of this method of examination are its non-invasive nature, its repeatability and the fact that it gives immediate results. In addition to this it is possible to analyse regions of interest (ROI) of the entire equine endometrium. Costs and practicability of the equipment are factors which need to be improved in further investigations.
\end{abstract}

Keywords: mare, endometrium, uterus, ultrasonography, computer assisted grey scale analysis, tissue characterization

\begin{abstract}
Ultrasonographische Graustufenanalysen (GSA) des Uterus der Stute - praktische Bedeutung für die Fruchtbarkeitsprognose
In der Humanmedizin wird die Graustufenanalyse (GSA) von Ultraschallibildern als Ergänzung der Ultrasonographie zur Beantwortung spezifischer Fragestellungen eingesetzt (Lieback et al. 1991; Raeth et al. 1984). Hermes et al. (1997, 1998) haben diese Untersuchungsmethode in der Zoo- und Wildtiermedizin eingesetzt.

Mit Hilfe der computerunterstützten GSA von Ultraschallaufnahmen des Endometrium der Stute ist es möglich, zwischen einem physiologischem Endometrium und einem entzündlich/degenerativ verändertem Endometrium zu unterscheiden. Diese Untersuchungsmethode konnte als diagnostisches Hilfsmittel neben der mikrobiologischen und pathohistologischen Untersuchung etabliert werden. Die Untersuchung ist nicht invasiv und jederzeit wiederholbar. Es besteht die Möglichkeit „Regions of interest“ (ROI) aus dem gesammten ultrasonographisch dargestelltem Endometrium zu analysieren und die Ergebnisse in kurzer Zeit zur Verfügung zu stellen. Als Nachteil werden hohe Anschaffungskosten und ein großer Geräteaufwand angesehen.
\end{abstract}

Schlüsselwörter: Stute, Endometrium, Uterus, Ultraschall, computerunterstützte Graustufenanalyse, Gewebeanalyse

\section{Introduction}

Ultrasonography of the mare's reproductive tract is an essential part of the gynaecological examination. The interpretation of ultrasonographic images is important in determining fertility prognosis.

Visual analysis and interpretation of ultrasonographic images is restricted through a loss of information. This is caused by the human eye's limited ability in distinguishing grey scales as well as the influence of subjective factors. Computer assisted grey scale analysis (GSA) combines advanced ultrasonography with image analysing systems. In human medicine ultrasonography, computer assisted GSA is well established (Lieback et al. 1991, Raeth et al. 1984 and Mueller et al. 1989). Hermes et al. $(1997,1998)$ applied computer assisted GSA in zoo and wildlife medicine. Ultrasonographic images of the endometrium of the roe deer were analysed to characterise changes of the endometrium during embryonic diapause.

The purpose of this study was to incorporate GSA into equine gynaecological ultrasonography and to use it to objectify physiological and pathological variations in ultrasonographic echotexture of the equine endometrium.

\section{Material and methods}

\section{Mares}

Seven mares ( $n=7$; group 1) were examined in the main study over a time period of ten to twelve weeks. In estrus and when the follicle diameter was more than $30 \mathrm{~mm}$ examinations were carried out in 24 hour intervals until six days post ovulation. In diestrus the mares were examined every two or three days.

In addition to the main study there was a second group with three mares (group $2 ; n=3$ ).

These mares were referred to the clinic with endometritis. The computer assisted GSA was performed in the preovulatory time ( $1-4$ days before ovulation). The lowest mean median of the grey scale histogram during this time was compared with the results of the gynaecological, microbiological and pathohistological examinations.

\section{Examination}

Prior to the examination period a biopsy of the endometrium was taken. A uterine swab for bacteriological cultering was taken once in a sexual cycle. 
The aim of ultrasonographic examination was to provide representative and artefact free sonographic images of the ovaries and the uterus. To obtain comparative results the ultrasonographic examinations and the grey scale analysis were carried out under identical conditions. Frequency (7.5 MHz), output, resolution, gain, depth of penetration and correlation of the ultrasound machine SONOLINE VERSA PRO (Fa. Siemens) were kept on the same standard values throughout the study. The mares were treated with $0.2 \mathrm{mg} / \mathrm{kg}$ bwt N-Butylscopolamin-bromid (Buscopan®, Fa. Boehringer) to avoid the influence of intestinal contractions during the examination. Prior to the examination, faeces were removed from the horses' rectum and $100 \mathrm{ml}$ lubricant was applicated. The ultrasonographic examination includes the ovaries, the uterine horns and the uterine body in cross section. The entire examination was recorded on S-VHS videotapes for retrospective analysis.

\section{Analysis}

The analysing system consisted of a video recorder, a monitor, and a PC equipped with a frame grabber card. Single video frames were digitised and analysed using the software program ANALYSIS PRO (Soft Imaging Software Gmbh, Münster). After selection and digitisation of representative artefact free images from the videotape a so called region of interest ( $\mathrm{ROI})$ was selected. The region of interest was always projected into the endometrium at a depth of penetration of $1-2 \mathrm{~cm}$. The ROI had a size of $16 \times 16$ Pixel (Fig. 1).

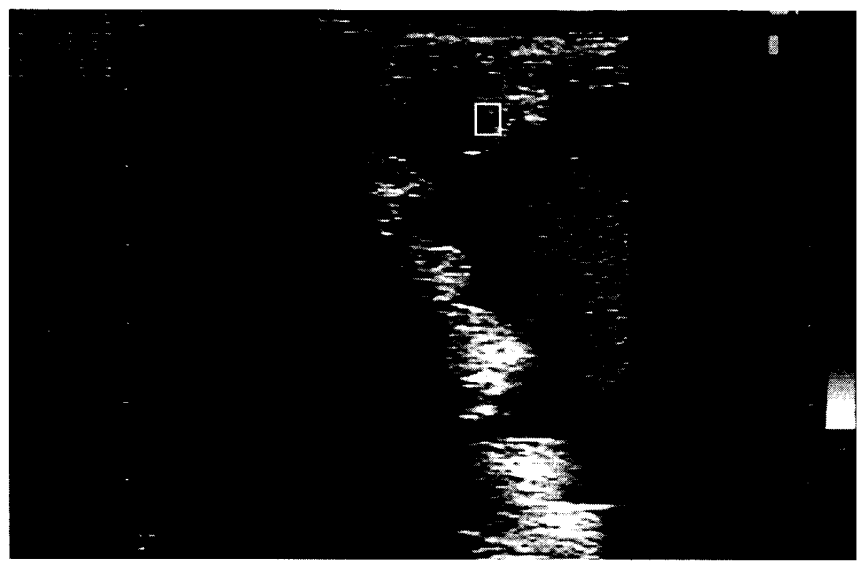

Fig. 1: Ultrasonographic image of inflammatory changed endometrium with "region of interest" (yellow) in a maximum depth of penetration of two centimetres (red).

Ultraschallbild von entzündlich verändertem Endometrium mit eingezeichneter "region of interest" (gelb) in einer maximalen Eindringtiefe von zwei Zentimeter (rot).

Using the software ANALYSIS PRO 256 different grey scales were determined. Based on the distribution of grey scales a histogram was calculated from which the median and standard deviation were determined. GSA were performed at three different positions within one image. Per examination three images of the uterine horns and the uterine body were analysed. Mean median and the standard deviation (SD) of the mean was calculated for each examination (Fig. 2).

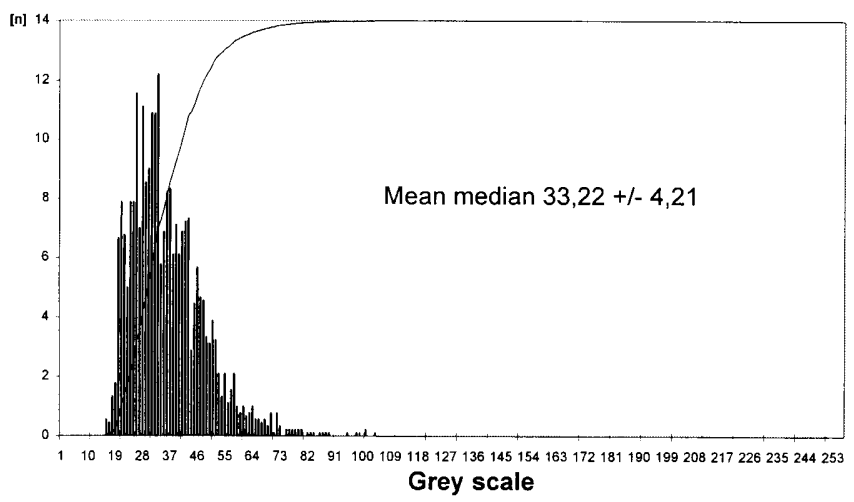

Fig. 2: Grey scale histogram with mean median and standard deviation from a mare with physiological endometrium two days before ovulation.

Graustufenhistogramm mit mittleren Median und Standardabweichung einer Stute mit physiologischem Endometrium zwei Tage vor der Ovulation.

\section{Results}

\section{Group 1}

Figure 3 gives an example of the results obtained showing the mean median of the grey scale histogram during one sexual cycle from two of the seven mares out of group 1 . Mare A had no signs of uterine inflammation and the uterine swab was free of pathogenious micro-organisms. Mare B was infected with $\beta$-hem. sc. and had uterine inflammation. Due to the pathohistological findings mare A was categorised I and mare B was categorised III according to Kenney and Doig 1986.

Physiological endometrium (as seen in mare A figure 2) showed a preovulatory decrease in the mean median of the grey scale histogram $(33.24 \pm 4.21)$. Based on these changes a prediction of ovulation was possible $(3 \pm 1$ day after decrease of mean median). After the preovulatory decrease the mean median increase till three days after the ovulation.

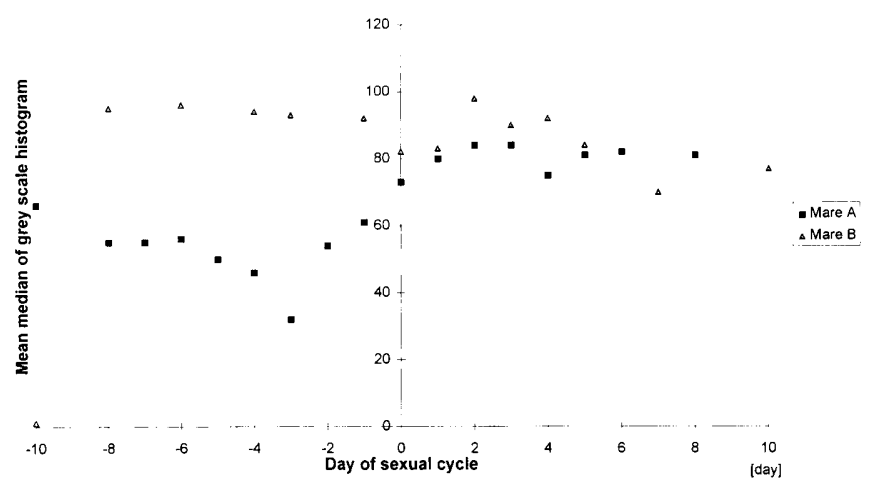

Fig. 3: Mean median of grey scale histogram during sexual cycle. $A=$ mare with physiological endometrium, $B=$ mare with inflammatory changed endometrium

Verlauf der mittleren Mediane der Grauwerthistogramme während des Zyklus. A=Stute mit physiologischem Endometrium, $B=S$ Stute mit entzündlich verändertem Endometrium. 
Three days post ovulation the values of the mean median remained constant $(80,23 \pm 6,64)$.

Endometrium altered through inflammation (as seen in mare $B$ figure 2) did not show a preovulatory decrease in the mean median $(97.67 \pm 13.82)$. The prediction of the ovulation was not possible.

\section{Group 2}

The decrease of the lowest preovulatory mean median from the first cycle to the second cycle as seen in mares no 1 and no 3 correlates well with a decrease of the clinical signs of the uterine inflammation and the improvement of the microbiological and pathohistological results (tab. 1, 3). The mean median of the grey scale histogram from the endometrium of mare No 2 did not show a preovulatory decrease in the following cycles during the treatment of the uterine inflammation (tab. 2). In the third cycle the uterus was found to be free of pathogenious bacterias but the pathohistological examination showed that the mare still suffered from endometritis and endometrosis.

Tab. 1: Lowest preovulatory mean median of grey scale histogram compared with results of gynaecological, microbiological and pathohistological examination of mare no. 1 . ( $+=$ low grade, $++=$ medium grade, $+++=$ severe)

Vergleich der Ergebnisse der klinisch gynäkologischen, der mikrobiologischen und der pathohistologischen Untersuchungen mit dem niedrigsten präovulatorischen mittleren Median des Grauwerthistogrammes Stute Nr.1. (+ = geringgradig, $++=$ mittelgradig, $+++=$ hochgradig)

\begin{tabular}{|l|c|c|c|c|}
\hline mare no 1 & $\begin{array}{c}\text { clinical } \\
\text { signs of } \\
\text { inflamm. }\end{array}$ & $\begin{array}{c}\text { microbiol. } \\
\text { exam. }\end{array}$ & $\begin{array}{c}\text { pathohistol. } \\
\text { examination }\end{array}$ & $\begin{array}{c}\text { preovulat. mean } \\
\text { median of grey } \\
\text { scale histogram }\end{array}$ \\
\hline 1. cycle & +++ & +++ & $\begin{array}{c}\text { endometritis+++ } \\
\text { endometrosis++ }\end{array}$ & $88,44 \pm 14,24$ \\
\hline 2. cycle & + & + & $\begin{array}{c}\text { endometritis+ } \\
\text { endometrosis++ }\end{array}$ & $47,56 \pm 7,84$ \\
\hline 4. cycle & - & + & $\begin{array}{c}\text { endometritis- } \\
\text { endometrosis+/++ }\end{array}$ & $45,78 \pm 6,24$ \\
\hline
\end{tabular}

\section{Discussion}

Although computer assisted image analysing has been in use in human medicine for nearly two decades (Schlaps 1983 ) its use in veterinary medicine is limited. Hermes et al. $(1997,1998)$ studied the endometrium of roe deer. Based on grey scale analysis of the endometrium they were able to distinguish between pregnant and non pregnant animals during the period of embryonic diapause.

The computer assisted grey scale analysis of ultrasonographic images offered the possibility to quantify structural changes of the examined tissue.

The computer assisted GSA was a suitable method to document changes in the equine endometrium. In the preovulatory period it is possible to distinguish between physiological and inflammatory changed endometrium. The endo- metrial fluid accumulation, caused by the influence of oestrogens were responsible for the preovulatory decrease of the mean median. Inflammatory reactions correlated with a high echogenity of the endometrium. Therefore we did not see the typical decrease of the mean median of the grey scale histogram of inflammatory changed endometrium. The results of this study introduce computer assisted GSA as an additional diagnostic tool in equine gynecological ultrasonography.

Tab. 2: Lowest preovulatory mean median of grey scale histogram compared with results of gynaecological, microbiological and pathohistological examination of mare no.2. $(+=$ low grade, $++=$ medium grade, $+++=$ severe)

Vergleich der Ergebnisse der klinisch-gynäkologischen, der mikrobiologischen und der pathohistologischen Untersuchungen mit dem niedrigsten präovulatorischen mittleren Median des Grauwerthistogrammes der Stute Nr. 2. ( + = geringgradig, $++=$ mittelgradig, $+++=$ hochgradig)

\begin{tabular}{|c|c|c|c|c|}
\hline mare no 2 & $\begin{array}{c}\text { clinical } \\
\text { signs of } \\
\text { inflamm. }\end{array}$ & $\begin{array}{c}\text { microbiol. } \\
\text { exam. }\end{array}$ & $\begin{array}{c}\text { pathohistol. } \\
\text { examination }\end{array}$ & $\begin{array}{c}\text { preovulat. mean } \\
\text { median of grey } \\
\text { scale histogram }\end{array}$ \\
\hline 1. cycle & +++ & +++ & $\begin{array}{c}\text { endometritis++ } \\
\text { endometrosis+++ }\end{array}$ & $92,89 \pm 15,07$ \\
\hline 2. cycle & + & + & & $90,67 \pm 15,67$ \\
\hline 3. cycle & ++ & - & endometritis++ & $89,78 \pm 11,09$ \\
\hline
\end{tabular}

During the treatment of endometritis the computer assisted GSA was a useful diagnostic tool in order to quantify the healing process and the therapeutical success.

Further investigations of the endometrium will be concentrated around the preovulatory period. The aim of such investigations would be to define standard values for mares with physiological endometrium and those with endometritis and endometrosis.

The advantages of this method of examination are its non- invasive nature, its repeatability and the fact that it gives immediate results. In addition to this it is possible to visualise the entire equine uterus ultrasonographically. It is therefore possible to analyse regions of interest of the whole endometrium.

Tab. 3: Lowest preovulatory mean median of grey scale histogram compared with results of gynaecological, microbiological and pathohistological examination of mare no.3. ( $=$ low grade, $++=$ medium grade, $+++=$ severe)

Vergleich der Ergebnisse der klinisch-gynäkologischen, der mikrobiologischen und der pathohistologischen Untersuchungen mit dem niedrigsten präovulatorischen mittleren Median des Grauwerthistogrammes der Stute Nr. 3 (+ = geringgradig, $++=$ mittelgradig,$+++=$ hochgradig)

\begin{tabular}{|c|c|c|c|c|}
\hline mare no 3 & $\begin{array}{c}\text { clinical } \\
\text { signs of } \\
\text { inflamm. }\end{array}$ & $\begin{array}{c}\text { microbiol. } \\
\text { exam. }\end{array}$ & $\begin{array}{c}\text { pathohistol. } \\
\text { examination }\end{array}$ & $\begin{array}{c}\text { preovulat. mean } \\
\text { median of grey } \\
\text { scale histogram }\end{array}$ \\
\hline 1. cycle & +++ & +++ & endometrosis+ & $67.22 \pm 9.23$ \\
\hline 2. cycle & - & - & & $48.12 \pm 5.46$ \\
\hline
\end{tabular}


Disadvantages include the high costs and the practicability of the equipment

\section{Literature}

Brück, I. (1994): Ultraschalldiagnostik am Genitaltrakt der Stute. Pferdeheilkd., 10, 161-172

Gertsch, Ursula (1997): Bildanalytische Untersuchungen zur Bestimmung der Oedematisierung des Uterus bei der Stute. Dissertation, Bern

Ginther, O.J., and R.A. Pierson (1984): Ultrasonic anatomy and pathology of the equine uterus. Theriogenology. 21, 505-516

Hermes, R. (1998): Sonographie der Trächtigkeit beim Europäischen Reh (Capreolus capreolus) und Quantifizierung endometrialer Veränderungen während der Diapause mittels computergestützter Graustufenanalyse. Dissertation, Freie Universität Berlin, 1-119

Hermes, R., T. B. Hildebrandt, F. Göritz, T. Lengwinat, K. Jewgenow and R.R. Hoffmann (1997): Sonographie der Trächtigkeit beim europäischen Reh (Capreolus Capreolus) - Diapause Embryonal und Fetalentwicklung, Embryonale Resorptionen. Verh. Ber. Erkrg. Zootiere, 38. 169-173

Kähn, W. and W. Leidl (1985): Sonographische Befunde am Uterus von Stuten mit Uitraschall bei einer Frequenz von 5 Megahertz $\left(\mathrm{MH}_{\mathrm{z}}\right)$. Pferdeheilkd., 1, 239-246

Kenney, R. M. and Doig, P. A. (1986): Equine endometrial biopsy. In Current Therapy in Theriogenology, 2nd Edition. Ed. D. A. Morrow, W. B. Saunders, Philadelphia, 723-729

Lieback, E., Nawrocki, M., Meyer, R., Vilser, J., Bellach, J. and R. Hetzer (1991): Erkennung einer Abstossungsreaktion nach Herztransplantation durch echokardiographische Gewebecharakterisierung. Z. Herz-, Thorax-, Gefäßchir. 5, 207-214

Lorber, K.J., Bartmann, C.P., Klug, E. and R. Hermes (1999): Examination of the equine endometrium with computer assisted Grey Scale Analysis (GSA). Reprod. Dom. Anim. 34, 31

McKinnon, A.O., E.L. Squires, E.M. Carnevale, L.A. Harrison, D.D. Frantz, A.E. McChesney and R.K. Shideler (1987): Diagnostic ultrasonography of uterine pathology in the mare. Proc. Annu. Conv. Am. Assoc. Equine Pract. 33, 605-622

Merkt, H., A.R. Günzel, W. Abel and R. Mattos (1983): Echographie -eine Ergänzung der gynäkologischen Untersuchungsmethoden zur Zykius- und Trächtigkeitsdiagnostik beim Pferd. Dtsch. tierärztl. Wochenschr., 90, 225-230
Mueller, M. J., D. Lorenz, I. Zuna, W. J. Lorenz und G. Van Kaick (1989): Die Wertigkeit der computerunterstützten sonographischen Gewebscharakterisierung bei fokalen Läsionen der Schilddrüse. Radiologie, Vol. 29, 132-136

Raeth; U., I.Zuna, B. Limberg, D. Schlaps, A. Lorenz, G. Van Kaick, W.J. Lorenz und B. Kommerell (1984): Der Beitrag der Grauwerthistogram -Analyse zur sonographischen Diagnostik des diffusen Leberparenchymschadens. Ultraschall, Vol. 5, No. 3, 94-97

Schlaps, D. (1983): Gewebedifferenzierung durch Computerechographie - Entwicklung eines Verfahrens zur Texturanalyse des Ultraschall B-Bildes. Dissertation, Universität Mainz

Karl Lorber

Uta Blaich

Erich Klug

Claus-Peter Bartmann

Klinik für Pferde

Tierärztliche Hochschule Hannover

Bischofsholer Damm 15

D-30173 Hannover

Tel. : 05118567233

H. -A. Schoon

Institut für Veterinär-Pathologie

Veterinärmedizinische Fakultät

An den Tierkliniken 33

D 04103 Leipzig

Tel.: $0341-9738270$

Fax: $0341-9738290$

Robert Hermes

Institut für Zoo- und Wildtierforschung (IWZ)

Alfred-Kowalke-Str. 17

D 10315 Berlin

Tel.: $030-5168715$

Fax: $030-5126104$ 